DOI: https://doi.org/10.31933/dijdbm.v2i6 Received: $16^{\text {th }}$ October 2021, Revised: $1^{\text {st }}$ November 2021, Publish: $30^{\text {th }}$ November 2021

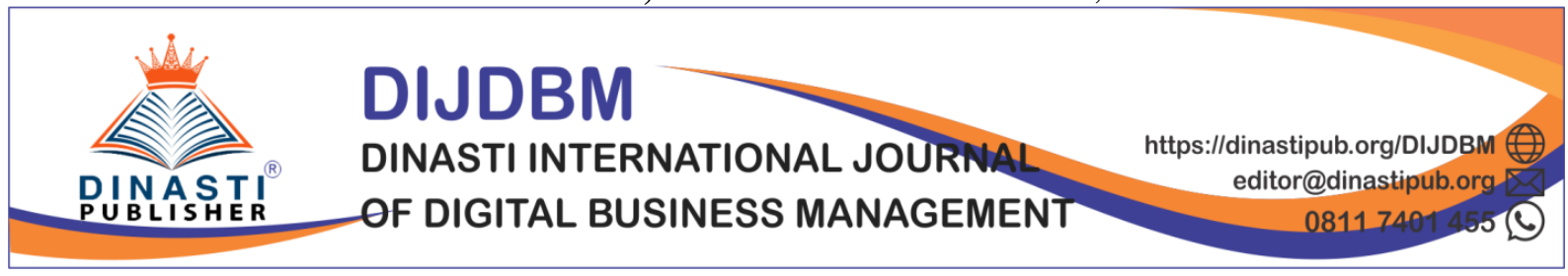

\title{
THE REVIEW OF LEADERSHIP STYLE, EMPLOYEE PROMOTION, AND MOTIVATION
}

\author{
Hari Kurniawanto ${ }^{1}$, Anoesyirwan Moeins ${ }^{2}$, Djoko Herwanto ${ }^{3}$ \\ ${ }^{1)}$ Curug Indonesia Aviation Polytechnic (PPIC), harikur@yahoo.com \\ ${ }^{2)}$ Universitas Persada Indonesia YAI. Jakarta, Indonesia. \\ 3) Politeknik Penerbangan Indonesia Curug. Indonesia.
}

Corresponding author: Hari Kurniawanto

\begin{abstract}
This research is conducted to obtain various gathered to be data analyzes and interpretations so that we can get a picture concerning the influence of leadership on the execution of officer promotion and its implication to officer motivation. The research method used is the descriptive survey method and survey of explanatory. The sample size is 100 officer people. The unit analyzes in this research is cross-sectional. The result of this research is leadership in PT. Telkom Kandatel South Jakarta in general goodness. The Officer promotion in PT. Telkom Kandatel South Jakarta, in general, is good enough. The administration affects officer promotion, the administration has an impact on officer motivation, and advertising affects officer motivation
\end{abstract}

Keyword: Style of Leadership, execution of officer promotion, motivation

\section{INTRODUCTION}

At the beginning of the 21st century, the era of globalization with the enactment of APEC in 2020 will require every business person to make strategic adjustments that allow them to win the competition. The business environment in the future will become more challenging to control, uncertain and unpredictable. The conditions faced by business people are "what remains is change" and "what is certain is uncertainty." This situation will be met by all business people, the private sector, BUMN (State-Owned Enterprises), and even cooperatives.

The complexity of competition in the telecommunications service industry increases with the enactment of Law no. 36/1999 concerning Telecommunications. This has encouraged PT TELKOM INDONESIA to develop its business strategy. By TELKOM INDONESIA's Corporate Dominance Branding Strategy to form a strong Brand Equity, consistent implementation is applied to continuously improve the quality of its services to achieve service excellence, namely speed, accuracy, comfort, and friendliness, so that it is expected that the public/ customers continue to choose and use TELKOM INDONESIA company products which in turn can increase market share in the future. 
In achieving PT.TELKOM's goals cannot be separated from the human resources they have because human resources in the telecommunications service business and infrastructure have a significant role in shaping the value of telecommunications services themselves to achieve substantial revenue growth. But in reality, based on observations and interviews conducted, Ahmad (2003) turned out that the work motivation of employees of PT. TELKOM Kandatel South Jakarta, especially the most employees, namely employees who have relatively low D2 education and below, this can be seen from the negative, unmotivated complaints, and seem to work as they please, so that it has an impact on their work performance,

Based on the statement above, the low motivation of employees of PT. TELKOM Kandatel South Jakarta is suspected of implementing a relatively inaccurate employee promotion, although the promotion rules for employees ex-D2 education and below during the transition period according to the Decree of the Board of Directors of PT. TELKOM INDONESIA Number: KD.34/ PS180/ SDM-12/ 99 Dated October 14, 1999, it is relatively straightforward, but the implementation of employee promotion itself is still felt to be unfair by employees, meaning that employees who are eligible according to the provisions are not promoted, but employees who do not deserve to be enabled, this can be seen from almost $45 \%$ of employees who have met the promotion requirements as stated in the promotion rules above and the condition that the formation is available, they have not been promoted,

If the leadership style at PT. TELKOM Kandatel South Jakarta is still oriented to power (power orientation). The promotion will not be appropriate so that it impacts the low work motivation of employees. If this continues, it is feared that the company's goals will not be achieved and will eventually lose out to other telecommunication services. . Therefore, it is necessary to examine the extent of the influence of leadership on the implementation of employee promotions, as well as its implications for work motivation. This study uses a human resource management approach as a grand theory, service management as a middle-range theory, and leadership, motivation, and promotion theories as applied theory.

This research was conducted to obtain various collected data analyzed and interpreted to obtain an overview of the influence of leadership on the implementation of employee promotions and their implications for employee motivation.

The research objectives are to:

1. Knowing the influence of leadership style on the implementation of employee promotions.

2. Knowing the influence of leadership style on employee motivation.

3. Knowing the effect of implementing employee promotions on employee motivation.

\section{METHODOLOGY}

Considering the nature of this research is descriptive and verification, the research method used is the descriptive survey method and explanatory survey method. The type of investigation in this study is causality. The unit of analysis in this study is the individual, namely the employees of PT. Telkom Kandatel South Jakarta Ex-D2 education. The time horizon in this study is cross-sectional, ie information from part of the population (responder 
sample) is collected directly from the location empirically, with the aim of knowing the opinion of some of the population on the object being studied.

The sampling technique used in this study is probability sampling, which is a sampling technique that provides equal opportunities for each element (member) of the population to be selected as a member of the sample. While the sampling method used is simple random sampling proportionally. The population in this study were employees of South Jakarta Kandatel ex-D2 PT. TELKOM.

\section{RESULT AND DISCUSSION}

\section{Leadership at PT. Telkom Kandatel South Jakarta}

From the results of the study indicate that in general the leadership at PT. Telkom Kandatel South Jakarta is quite good, the leadership ability can be seen from how the leader directs the actions or activities of the leader which can be seen from the responses of the people he leads. Apart from that, it can also be seen from how the support from all subordinates in carrying out the main tasks of the organization is described and manifested through the decisions and policies of the leadership.

In general, a leader should meet the following characteristics: Have a broad education, the ability to develop mentally, curious, have analytical skills, have a strong memory, integrative capabilities, communication skills, rationality and objectivity, sense of urgency, sense of timing, sense of cohesiveness, sense of relevance, simplicity, courage, listening and decisiveness.

From the description above, it shows that the implementation of leadership has a significant influence on employee motivation. In other words, the more leadership felt by employees, the more employee performance will improve.

\section{Employee Promotion at PT. Telkom Kandatel South Jakarta}

With implementation Promotions that are carried out regularly will increase work motivation so that performance will also increase. The results of the study indicate that there is a significant and positive effect between the implementation of promotions on employee motivation, meaning that the better the implementation of the promotion, the work motivation will increase. so that PT. Telkom Kandatel South Jakarta through the HR Division can focus on promotions to increase employee motivation, by paying attention to the employee's tenure and level of the employee. This is in accordance with the opinion of Hasibuan $(1994,123)$ adding that in addition to seniority and work performance, there is also a combination of work performance and seniority. The purpose of the combination is that both are considered to see whether the employee deserves to be promoted or not.

\section{Employee Work Motivation at PT. Telkom Kandatel South Jakarta}

Motivation as an urge to do a job with passion and comes from within the human being himself (intrinsic) and can also come from outside the human being (extrinsic). Intrinsic motivation factors include personality, attitude, work experience, level of formal education, as hopes or aspirations that reach into the future. Extrinsic motivational factors include the work environment, work culture in the organization, coworkers (colleagues), work equipment and 
many other factors. In practice, the two forms of motivation (intrinsic and extrinsic) are interrelated, because a person will always interact with his environment.

Overall employee motivation of PT. Telkom Kandatel South Jakarta is considered quite good, especially the response and responsibility in handling work. The quality of work standards that have been set have been achieved by most of the employees. Employees always try to improve the quality of their work and work well even without the supervision of superiors. Motivation can also be measured through the enthusiasm and responsibility of employees and in this case it is considered very good.

\section{CONCLUSION}

1. Leadership at PT. Telkom Kandatel South Jakarta is generally good, because the main characteristics that influence a person's success to lead an organization are intelligence, maturity and social relations, self-motivation and drive for achievement, and human relations attitudes, all of which can improve employee performance. Leadership is also proven to affect the implementation of employee promotions. Likewise, employee motivation is proven to be influenced by leadership.

2. Employee promotion by PT. Telkom Kandatel South Jakarta is generally quite good, the promotional programs offered are in accordance with the years of service and work performance and are fairly fair in determining the promotions carried out. Employee promotions are proven to affect employee motivation.

3. Leadership that must be considered is attention to suggestions and opinions in setting policies, conducting deliberation when solving problems, brainstorming in asking for opinions, explaining the duties of each member, openness, making changes according to the current environmental situation, giving and paying attention to employees. .

4. Employees are motivated if given the opportunity to convey ideas / ideas, suggestions and input from subordinates are taken into consideration for decision making, are involved in discussing issues, pay attention to subordinate complaints, complete facilities, awards, and employee career development.

\section{BIBLIOGRAPHY}

Ahmad Bahrudin, Employee Promotion at PT. Telkom, PT. Telkom, South Jakarta, 2003.

Arikunto Suharmini, Research Management, Rineka Cipta, Jakarta 1995.

1996

, Research Procedures A Practical Approach, Rineka Cipta, Jakarta,

As'ad Moh, Industrial Psychology, Liberty, Yogyakarta, 2000.

Bambang Kusriyanto, Increasing Employee Productivity, PT. References

Presindo, Jakarta, 1993.

Boulter, John, Behavior in Organizations, Volume I, Erlangga, Jakarta, 1995.

Behavior in Organizations, Volume II, Erlangga, Jakarta, 1997.

Birdir, Edwin, Human Resources Planning, Mc. Graw Hill Book Company, New York, 2000

Davis Keith, New Strom, John W, Behavior in Organizations, Volume I, Erlangga, Jakarta, 1995. 
Denton, Robert, , Organizational Planning, Mc. Graw Hill Book Company, New York, 1995.

Dessler Gary, Human Resources, Benjamin Molan Translation, PT. Prenhallindo, Jakarta, 1998.

Flippo, Edwin, Human Resources Management, Mc. Graw Hill Book Company, New York, 1984.

Gibson, Steven, Human Resources, Adriani Translation, PT. Prenhallindo, Jakarta, 2001.

Handoko Hani T, Personnel Management and Human Resources, BPFE, Yogyakarta, 1997.

Hasibuan, Personnel Management, BPFE, Yogyakarta, 1994.

Hronec, Fred E, A Theory of Leadership Effectiveness, Mc. Graw Hill Book Company, New York, 1993.

Hezberg F, Work and The Nature of Man Leveled, World Publishing, 1996.

Johnston, James L, John M Ivancevich, James H Donnely Jr., Organization, Behavior, Structure, Process, Nunuk Adriani Translation, Binarupa Aksara, Jakarta, 1995.

Kandola, John., Human Resources Management Hand Book, McGraw Hill, New York, 1996. Manulang, Personnel Management, Ghalia Indonesia, Jakarta, 1990.

Mangkunegara, Anwar Pabu, Personnel Management, Ghalia Indonesia, Jakarta, 2001.

Mathis, RL \& Jackson, JH. Human Resource Management.PT. Salemba Emban Patria . Jakarta, 2000. .. Advanced Human Resource Management,.PT. Salemba Emban Patria. Jakarta, 2001.

Maskat H. Djunaidi, Effective Leadership within the Police, Sanyata Sumanasa Wira Sespim Polri, South Jakarta, 1992.

Milkivich, GJ \& Bourddreau, JW Human Resource Management. Richard D. Irwin. Chicago, 1997.

Moenir, Rewards and Punishments, Andi Offset, Yogyakarta, 1990.

Mustafa Zainal Eq, Introduction to Applied Statistics for Economics, BPFE-UII, Yogyakarta, 1990.

Nawawi, Usman, Human Resources, Mount Agung, Jakarta, 2000.

Nitisemito, Alex S. Human Resource Management, Mount Agung, Jakarta, 1997.

Robbins, S. Organization Theory; Structure, Design, and Application. Translated by Yusuf Udaya. Prentice-Hall. Inc. New Jersey. 1994.

Rowe, Jackson, Increase Competency, Richard D. Irwin. Chicago, 1955.

Siagian Sondang P, Human Resources Development, Mount Agung, Jakarta, 2003.

Sikula M, What and How Productivity, Persada Press Script, Jakarta, Without Years, 1981.

Simamora Henry, Human Resource Management, Publishing Department, YKPN College of Economics, Yogyakarta, 1999.

Sucherly, Competitive Advantage for Business and Non-Business Organizations, Professor Inauguration Oration, UNPAD, South Jakarta, 2003.

Sunad, Husnan and Heidjrachman, Performance Assessment and Employee Development, BPFE, Yogyakarta, 1990.

Syafiie Inu Kencana, Government Management, PT. Percha, Jakarta, 1998. 
Sekaran Uma, Research Methods For Business, Third Edition, John Wiley \& Sons, Inc., New York, 2000.

Spencer, M. Lyle and Spencer, M. Signe. Competence at Work: Model for Superior, 1993.

Wahjusumidjo, Leadership and Motivation, Ghalia Indonesia, Jakarta, 1994.

Wekley and Yulk, Motivation and Productivity, Third Edition, John Wiley \& Sons, Inc., New York, 1992.

Winardi, J, Conflict Management and HRM, Gramedia, Jakarta, 2002. 